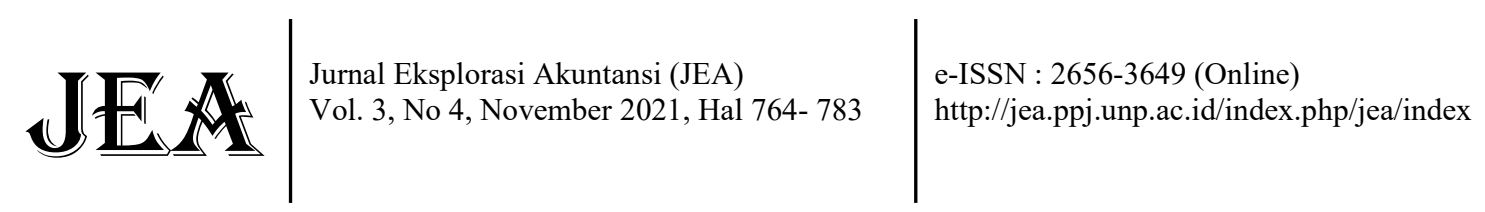

\title{
Komponen-Komponen Other Comprehensive Income dan Relevansi Risiko Comprehensive Income
}

\author{
Adriansyah $^{1 *}$, Herlina Helmy ${ }^{2}$ \\ 1,2 Fakultas Ekonomi, Universitas Negeri Padang \\ *Korespondensi: adriansyah1696@gmail.com
}

\begin{abstract}
This study aims to examine the risk relevance net income, comprehensive income, and component-competent other comprehensive income. Specifically, this study investigates the risk relevance of net income volatility, comprehensive income volatility, and componentcomponent other comprehensive income volatility on stock return volatility. The study population was finance and banking companies listed in Indonesia Stock Exchange period 2013-2017. Samples are selected with purposive sampling method. This study employed a quantitative method with simple linear regression because for variable tested had a number of different samples. The result of this research showed the risk relevance net income and comprehensive income can not be proven statistically. But of the five component of OCI only volatility change in the fair value of a financial instrument in a cash flow hedge are shown to have a significant positive effect on volatility stock return..
\end{abstract}

Keywords : Risk Relevance; Net Income; Comprehensive Income; Component Other Comprehensive Income; Stock Return Volatility.

How to cite (APA $6^{\text {th }}$ style)

Adriansyah \& Helmy, H. (2021). Komponen-Komponen Other Comprehensive Income dan Relevansi Risiko Comprehensive Income. Jurnal Eksplorasi Akuntansi (JEA), 3 (4), 764-783.

\section{PENDAHULUAN}

Salah satu sumber informasi dalam menilai kinerja perusahaan adalah laporan keuangan. Laporan keuangan sangat berperan penting di pasar modal karena laporan keuangan banyak digunakan sebagai dasar acuan pengambilan keputusan investasi terutama oleh para investor. Laporan keuangan yang relevan sangat dibutuhkan oleh investor. Investor membutuhkan laporan keuangan yang relevan guna menentukan seberapa besar tingkat risiko dan return yang ada pada suatu investasi. Investasi yang dipilih oleh investor diharapkan dapat memberikan tingkat pengembalian (return) yang tinggi, namun kenyataannya investor kemungkinan menghadapi risiko yaitu ketidapastian (uncertainty) atas tingkat pengembalian (return) tersebut. Ketidakpastian (uncertainty) atas tingkat pengembalian (return) merupakan sebuah cerminan atas risiko yang bisa dilihat dari tingkat volatilitas yang diukur dengan menggunakan standar deviasi. Semakin tinggi nilai standar deviasi maka semakin tinggi pula risiko tersebut, begitu pula sebaliknya (Warner, 2009:36-37). Sebelum mengambil keputusan untuk menginvestasikan dananya pada suatu investasi, investor akan melakukan analisis terlebih dahulu menggunakan informasi akuntansi yang terdapat dalam laporan keuangan. 
Laporan keuangan di Indonesia mengalami beberapa perubahan akibat adanya konvergensi PSAK terhadap IFRS, salah satunya laporan laba rugi. Menurut PSAK 1 (2013) laporan laba rugi mengalami perubahan terminologi menjadi laporan laba rugi dan penghasilan komprehensif lain (OCI), yang terdiri atas laba rugi dan penghasilan komprehensif lain (OCI). Akibat dari penerapan PSAK 1 (2013) membuat laba perusahaan bukan hanya laba bersih seperti yang ada selama ini, namun ada ukuran lain yaitu laba komprehensif yang dinilai lebih relevan karena memasukkan item-item yang terdapat dalam penghasilan komprehensif lain (OCI). Menurut PSAK 1 (2013) pos-pos yang tercakup dalam komponen OCI antara lain : surplus revaluasi, keuntungan (kerugian) atas program manfaat pasti, keuntungan (kerugian) keuntungan (kerugian) selisih kurs atas penjabaran mata uang asing, keuntungan (kerugian) pengukuran kembali atas instrumen aset tersedia untuk dijual, keuntungan (kerugian) bagian efektif atas lindung nilai arus kas. Pengungkapan komponen penghasilan komprehensif lain (OCI) menjadi penting seiring dengan adanya peningkatan kompleksitas transaksi bisnis, seperti aktivitas operasi luar negeri, aktivitas pensiun perusahaan, dan perdagangan surat berharga (Smith dan Tse, 1998).

Penyajian laba komprehensif dan komponen OCI dalam laporan laba rugi dan penghasilan komprehensif lainnya (OCI) disatu sisi membuat laporan keuangan akan lebih relevan dan berguna bagi para investor. Namun disisi lain, dengan adanya laba komprehensif dan komponen OCI dianggap membuat laporan laba rugi dan penghasilan komprehensif lainnya (OCI) menjadi lebih kompleks. Menurut Black (2013) laba komprehensif mengindikasikan volatilitas dari periode ke periode dan hal itu berkaitan erat dengan kondisi pasar yang diluar kontrol pihak manajemen. Dengan munculnya laba komprehensif dan komponen OCI pada laporan laba rugi dapat membawa potensi salah interpretasi kinerja keuangan perusahaan yang berkaitan dengan volatilitas dan peningkatan risiko (Khan dan Bradbury, 2014). Dalam hal ini para pelaku pasar terutama investor bisa berasumsi bahwa tingginya volatilitas pada laba komprehensif dan komponen OCI berkaitan dengan tingginya risiko perusahaan. Pertanyaan yang timbul, apakah risiko yang terdapat dalam informasi laporan keuangan menjadi lebih relevan dan berguna bagi pengguna laporan keuangan terutama investor dalam pengambilan keputusan investasi. Maka, untuk menjawab pertanyaan tersebut perlu dilakukan penelitian relevansi risiko.

Suatu informasi dikatakan relevan apabila informasi tersebut digunakan dalam pertimbangan pengambilan keputusan. Beaver et al (1970) mendefinisikan relevansi risiko sebagai hubungan antara risiko informasi akuntansi dan ukuran risiko dipasar. Risiko informasi akuntansi dapat tercermin dalam volatilitas angka laba, yaitu laba bersih dan laba komprehensif (Khan dan Bradbury, 2014), serta volatilitas komponen OCI (Black, 2013). Sedangkan risiko di pasar tercermin dalam volatilitas return saham (Black, 2013; Khan dan Bradbury, 2014)). Penelitian ini fokus pada studi relevansi risiko terkait volatilitas angka laba (laba bersih dan laba komprehensif) dan komponen OCI terhadap risiko pasar yang tercermin dalam volatilitas return saham. Hasil penelitian sebelumnya terkait studi relevansi risiko menunjukkan hasil yang berbeda. Selain itu, penelitian terkait studi relevansi risiko masih bersifat terbatas terutama di Indonesia.

Penelitian relevansi risiko dilakukan oleh Khan dan Bradbury (2012) dengan melakukan pengujian terhadap perusahaan non-keuangan Selandia Baru yang menemukan bahwa volatilitas laba (laba bersih dan laba komprehensif) berhubungan positif dengan volatilitas return saham. Hasil yang sama dibuktikan oleh Black (2013) yang melakukan relevansi risiko dengan sampel perusahaan perbankan di US yang menemukan hasil bahwa volatilitas laba (laba bersih dan laba komprehensif) berhubungan positif dengan volatilitas return saham. Khan dan Bradbury (2014). melakukan penelitian kembali dengan sampel yang berbeda yaitu perusahaan non-keuangan Amerika Serikat, dan hasilnya sama dengan penelitian sebelumnya. Namun, berbeda dengan hasil penelitian diatas, Kouki et al. (2016) 
menemukan bahwa volatilitas laba (laba bersih dan laba komprehensif) tidak berpengaruh terhadap volatilitas return saham.

Dari komponen OCI, penelitian Maines dan Mcdaniel (2000) dan Bloomfield et al (2006) membuktikan bahwa keuntungan dan kerugian dari sekuritas tersedia untuk dijual berpengaruh terhadap volatilitas return saham (memliki relevansi risiko). Goncharov dan Hodgson (2011) menemukan keuntungan atau kerugian atas selisih kurs penjabaran entitas asing memiliki nilai yang relevan. Menurut Khan dan Bradbury (2012) menemukan bahwa revaluasi aset merupakan komponen utama dalam OCI yang membuat laba komprehensif menjadi lebih volatil terhadap laba bersih. Dan hasil berbeda ditemukan oleh O'Hanlon dan Pope (1999) menemukan bukti bahwa investor tidak menggunakan OCI serta pada umumnya komponen OCI dinilai konsisten artinya tidak ada mengalami perubahan secara signifikan. Black (2013) menemukan bahwa komponen OCI kategori fair value yaitu aset keuangan tersedia untuk dijual serta lindung nilai arus kas memiliki hubungan yang negatif terhadap volatilitas return saham. Sedangkan komponen OCI kategori accounting calculation yaitu program pensiun juga memiliki hubungan yang negatif terhadap volatilitas return saham.

Penelitian ini didasarkan pada penelititan yang telah dilakukan sebelumnya oleh Black (2013) dan Khan dan Bradbury (2014) yang meneliti tentang relevansi risiko. Perumusan masalah dalam penelitian adalah seberapa besar pengaruh relevansi risiko laba bersih, laba komprehensif, dan komponen-komponen OCI terhadap volatilitas return saham pada perusahaan sektor keuangan yang terdaftar di Bursa Efek Indonesia 2014-2017.

\section{REVIEW LITERATUR DAN HIPOTESIS Teori Pasar Efisien}

Menurut Eugene F. Fama (1970) pasar efisien adalah suatu kondisi pasar dimana harga pasar saham merefleksikan dengan sempurna (fully reflect) semua informasi yang tersedia. Suatu pasar dikatakan efisien apabila informasi atau sinyal tertentu berperilaku seakan-akan seluruh pelaku pasar menangkap sinyal tersebut kemudian berpengaruh terhadap keputusan investasi mereka (Suwardjono, 2013). Menurut Fama (1970) dan Suwardjono (2013), ada 3 bentuk efisiensi pasar berdasarkan tiga macam bentuk dari informasi (informasi historis, sekarang, dan informasi privat) yaitu efisiensi pasar bentuk lemah (weak form), efisiensi pasar bentuk setengah kuat (semi strong form) dan efisiensi pasar bentuk kuat (strong form). Para investor di Indonesia termasuk ke dalam efisiensi pasar bentuk setengah kuat, dimana investor memiliki akses atau kesempatan yang sama untuk menggunakan informasi yang dipublikasikan oleh perusahaan.

\section{Teori Sinyal (Signalling Theory)}

Teori sinyal didasarkan pada asumsi bahwa informasi yang dipublikasikan oleh perusahaan diterima oleh para pengguna laporan keuangan atau masing-masing pihak tidak sama. Hal ini disebabkan karena adanya asimetri informasi antara pihak internal perusahaan dan pihak eksternal. Oleh karena itu, manajer diwajibkan untuk memberikan informasi mengenai perusahaan melalui penerbitan laporan keuangan bagi pihak-pihak yang berkepentingan (Restuti, 2006). Informasi yang lengkap, relevan, akurat dan tepat waktu sangat diperlukan oleh investor di pasar modal sebagai alat analisis untuk mengambil keputusan investasi (Suwardjono, 2013).

Signaling theory menjelaskan terkait bagaimana seharusnya suatu perusahaan memberikan signal yang berguna bagi para pengguna laporan keuangan. Menurut Hartono (2010, 392), suatu informasi yang disajikan sebagai suatu pengumuman akan dianggap sebagai signal bagi para investor dalam pengambilan keputusan investasi. Apabila informasi tersebut positif, maka pasar akan bereaksi terhadap pengumuman tersebut sehingga terjadi perubahan dalam pasar terkait volume perdagangan saham. Jika informasi Laba bersih, laba 
komprehensif, OCI dan komponen-komponennya dianggap penting dan berguna maka para pengguna laporan keuangan terutama investor akan mengganggap informasi tersebut sebagai sinyal yang dijadikan sebagai bahan pertimbangan dalam pengambillan keputusan investasi.

\section{Relevansi Risiko}

Penelitian tentang relevansi risiko merupakan pengembangan dari penelitian relevansi nilai. Penelitian relevansi risiko melihat unsur risiko yang terdapat dalam informasi akuntansi pada laporan keuangan dan pengaruhnya terhadap reaksi pasar. Penelitian tentang relevansi risiko bertujuan untuk menguji hubungan antara risiko informasi akuntansi dan ukuran atas risiko di pasar (Beaver et al, 1970). Penelitian relevansi risiko seringkali diukur dengan hubungan antara volatilitas time-series dari item laporan keuangan dengan volatilitas timeseries dari return saham (Black, 2013). Penelitian ini fokus pada studi relevansi risiko yang meneliti hubungan statistikal antara risiko informasi akuntansi dengan ukuran risiko pasar. Ukuran variabel risiko informasi akuntansi diproksikan dengan volatilitas laba yaitu laba bersih dan laba komprehensif seperti pada penelitian Khan dan Bradbury (2014) dan volatilitas komponen OCI (Black, 2013). Dan ukuran atas risiko pasar dapat diproksikan dengan volatilitas return saham (Black, 2013; Khan dan Bradbury, 2014).

Penelitian relevansi nilai bisa dilakukan setelah informasi mengenai fundamental perusahaan pada saat dipublikasikan dengan melihat pengaruhnya terhadap pergerakan harga dan return saham di pasar. Sedangkan penelitian relevansi risiko merupakan pengembangan dari penelitian relevansi nilai, hal ini membutuhkan lebih dari dari satu periode waktu dari informasi akuntasi perusahaan untuk menjelaskan tingkat risiko dari pergerakan harga dan return saham di pasar yang menjadi penilaian bagi investor. Dalam hal ini bisa dikatakan, penelitian relevansi nilai menjelaskan hubungan pada momen pertama item pada laporan keuangan dipublikasikan dan pengaruhnya terhadap tingkat return saham pada saat itu, sedangkan penelitian relevansi risiko menjelaskan hubungan pada momen kedua item laporan keuangan dipublikasikan dan pengaruhnya terhadap perubahan return saham (Black, 2015).

\section{Pengaruh Volatilitas Laba Bersih terhadap Volatilitas Return Saham}

Pada studi relevansi risiko, volatilitas laba merupakan salah satu informasi akuntansi yang menunjukkan ukuran risiko dari suatu perusahaan. Volatilitas laba merupakan risiko bisnis yang melekat pada kegiatan operasi suatu perusahaan dianggap sebagai risiko bisnis akibat dari praktek manajemen yang tidak efisien (Khan dan Shah, 2007). Menurut Couto dan Rosa (2002) mengemukakan bahwa volatilitas laba merupakan hal yang penting dan dapat menjadi indikator awal mengenai ketidakpastian akan laba serta potensi terjadinya kegagalan atau bangkrutnya perusahaan. Dalam laporan keuangan, laba bersih dan laba komprehensif menjadi variabel pilihan untuk mengukur tingkat volatilitas laba perusahaan. Volatilitas nilai laba akan mempunyai relevansi risiko jika menimbulkan reaksi terhadap tingkat risiko dipasar. Reaksi yang terjadi pada risiko dipasar, salah satunya dapat dilihat dari tingkat perubahan (fluktuasi) return saham perusahaan yang menunjukkan tingkat risiko yang harus ditanggung oleh investor (Black, 2015). Informasi mengenai return perusahaan serta volatilitasnya merupakan komponen penting, terutama dalam menilai ketidakpastian arus kas masa depan.

Penelitian terdahulu tentang relevansi risiko dilakukan oleh Hodder et al (2005) dengan sampel perusahaan perbankan yang menguji hubungan antara volatilitas laba dengan volatilitas return saham. Volatilitas laba diukur dengan tiga model pengukuran (laba bersih, laba komprehensif, dan laba nilai wajar). Hasil penelitiannya menunjukkan bahwa volatilitas laba besih berpengaruh positif terhadap volatilitas return saham. Khan dan Bradbury (2012) melakukan penelitian pada perusahaan Selandia Baru sektor non-keuangan dari tahun 20032010. Hasil penelitiannya menunjukkan bahwa volatilitas laba bersih berpengaruh positif 
terhadap volatilitas return saham (risiko pasar). Penelitian Khan dan Bradbury (2014) dengan sampel perusahaan non-keuangan US dari tahun 2004-2010 menujukkan hasil bahwa volatilitas laba bersih berpengaruh positif terhadap volatilitas return saham (risiko pasar). Berdasarkan uraian di atas dirumuskan hipotesis sebagai berikut:

H1: Volatilitas laba bersih berpengaruh positif terhadap volatilitas return saham.

\section{Pengaruh Volatilitas Laba Komprehensif terhadap Volatilitas Return Saham}

Laba bersih pada dasarnya tidak terlalu mencerminkan perubahan nilai pasar dan kondisi perekonomian. Perubahan nilai pasar tercermin dalam laba komprehensif yang terdiri dari laba bersih dan penghasilan komprehensif lain (OCI). OCI mencakup perubahan pos aset dan liabilitas yang belum terealisasi sehingga sangat bergantung pada perubahan nilai pasar (Widiastuti, 2015). Menurut PSAK No 1 2013, Laba komprehensif (Comprehensive Income) adalah perubahan ekuitas selama satu periode yang dihasilkan dari transaksi dan peristiwa lainnya selain perubahan yang dihasilkan dari transaksi dengan pemilik dalam kapasitasnya sebagai pemilik. Laba komprehensif selain laba bersih juga berisi item-item penghasilan komprehensif lain (OCI) yang timbul karena penggunaan model nilai wajar dari dari aktivitas operasi perusahaan. Sifat dari komponen penghasilan komprehensif lain (OCI) yang merupakan unrealized gains or losses, akan membawa risiko bagi perusahaan karena nilainya sangat terpengaruh oleh kondisi pasar, sehingga membuat laba komprehensif menjadi tidak stabil dan sukar untuk diprediksi di masa depan bagi investor.

Laba komprehensif dinilai dapat meningkatkan transparansi informasi penting karena adanya unsur yang terdapat dalam OCI, sehingga laba komprehensif bisa memberikan informasi yang lebih akurat mengenai kondisi perusahaan sekarang. Namun, laba komprehensif memiliki potensi misinterpretasi yang kaitannya erat dengan volatilitas dan persepsi akan meningkatnya risiko (Khan dan Bradbury, 2014). Penelitian sebelumnya berkaitan dengan relevansi risiko dari laba komprehensif dilakukan Hodder et al. (2006) yang memberikan bukti bahwa laba komprehensif lebih volatil dibandingkan laba bersih, dan hasil penelitiannya menunjukkan bahwa volatilitas laba komprehensif berpengaruh positif terhadap volatilitas return saham (risiko pasar). Penelitian Khan dan Bradbury (2012) dengan sampel perusahaan non-keuangan Selandia Baru menunjukkan hasil bahwa volatilitas laba komprehensif berpengaruh positif terhadap volatilitas return saham (risiko pasar). Berdasarkan uraian di atas dirumuskan hipotesis sebagai berikut:

H2: Volatilitas laba Komprehensif berpengaruh positif terhadap volatilitas return saham.

\section{Pengaruh Perubahan dalam Surplus Revaluasi terhadap Volatilitas Return Saham}

Surplus revaluasi aset tetap adalah nama lain dari OCI terkait dengan revaluasi aset tetap. Menurut PSAK 16 tentang aset tetap, pengukuran aset dengan menggunakan metode revaluasi suatu aset tetap akan dicatat berdasarkan jumlah revaluasian. Metode revaluasi ini akan menghasilkan pengukuran aset dalam nilai sekarang atau nilai pasar (fair value) bukan nilai historis. Pengukuran menggunakan nilai sekarang (fair value) akan memberikan signal informasi mengenai nilai aset terbaru. Menurut Kahareningtyas (2016) pengukuran dengan fair value lebih dapat menggambarkan posisi real dan kinerja ekonomik perusahaan saat itu, sehingga informasi akuntansinya dapat lebih relevan. Namun disisi lain, unsur fair value pada revaluasi aset memliki risiko dalam nilai yang terdapat didalamnya serta memberikan ketidapastian di masa depan. Menurut Apandi (2015) Revaluasi aset merupakan salah satu komponen yang mempunyai tingkat subjektifitas yang tinggi karena aset yang dimiliki perusahaan mempunyai jenis yang berbeda-beda dan hal itu menyebabkan kerumitan dalam melakukan proses revaluasi yang sarat dengan asumsi dan estimasi. Selain menambah relevansi juga dengan adanya risiko tentunya akan menjadi informasi yang penting bagi 
investor dan hal itu akan bisa terlihat dari reaksi yang terjadi di pasar saham (perubahan harga saham atau return saham).

Penelitian sebelumnya belum ada yang meneliti secara langsung hubungan antara volatilitas revaluasi aset (surplus revaluasi) terhadap volatilitas return saham. Hubungan arah ini diteliti oleh Khan dan Bradbury (2012) dengan nama laba komprehensif disesuaikan (laba bersih ditambah khusus komponen OCI revaluasi aset) dan dilihat tingkat volatilitasnya. Khan dan Bradbury (2012) dalam peneltiannya menemukan bahwa laba komprehensif memiliki volatilitas yang lebih besar dari laba bersih sebesar $67,4 \%$. Volatilitas tersebut disebabkan oleh dominannya nilai dari item OCI revaluasi aset. Dorongan dari item OCI yang berdasarkan pengukuran nilai wajar memberikan dampak terhadap angka laba komprehensif dan membuatnya menjadi lebih volatil. Hasil dari peneltian Khan dan Bradbury (2012) menunjukkan bahwa volatilitas laba komprehensif dengan komponen khusus item OCI revaluasi aset berpengaruh terhadap volatilitas return saham. Berdasarkan uraian di atas dirumuskan hipotesis sebagai berikut:

H3a: Volatilitas surplus revaluasi aset tetap berpengaruh positif terhadap volatilitas return saham.

\section{Pengaruh Keuntungan atau Kerugian Aktuaria atas Program Manfaat Pasti terhadap Volatilitas Return Saham}

Keuntungan (kerugian) aktuaria atas program manfaat pasti terjadi karena adanya perbedaan asumsi atau taksiran terkait transaksi tersebut dari perhitungan sebelumnya dengan realisasi yang terjadi pada tahun berjalan. Keuntungan (kerugian) aktuaria atas program manfaat pasti dapat diakui sebagai beban pada saat terjadinya, akan tetapi perusahaan memiliki pilihan untuk mengakui keuntungan (kerugian) aktuaria program manfaat pasti bukan sebagai beban melainkan masuk ke dalam bagian penghasilan komprehensif lain (OCI). Program imbalan pasti memiliki perhitungan akuntansi dan administrasi yang lebih rumit dibandingkan dengan program iuran pasti, karena memerlukan variabel-variabel yang belum pasti di masa depan (Kahareningtyas, 2016). Program imbalan pasti mengharuskan perusahaan mengestimasikan nilai kini liabilitas dengan memperhitungkan beberapa unsur estimasi seperti usia pensiun, tingkat kematian, suku bunga diskonto, dan lainnya. Perlunya estimasi nilai dari program ini, karena adanya potensi keuntungan dan kerugian aktuarial. Dengan banyaknya variabel serta asumsi yang dibutuhkan dalam perhitungan nilai aktuaria atas program manfaat pasti membuat nilai OCI yang timbul atas aktivitas tersebut menjadi penuh dengan risiko atas ketidakpastian di masa depan.

Karena hal itu, komponen OCI keuntungan atau kerugian atas program manfaat pasti termasuk dalam salah satu kategori yang memiliki tingkat subyektifitas yang tinggi (Apandi, 2015). Risiko yang terdapat dari informasi OCI ini dapat menjadi signal bagi investor, yang membuat investor harus memiliki pengetahuan yang memadai guna menghadapi risiko tersebut agar menjadi pertimbangan dalam pengambilan keputusan investasi yang akan berdampak pada perubahan return yang diharapkan investor di pasar saham. Aldheimer \& Huynh (2014) melakukan penelitian dengan sampel data kuartalan 2009 dan 2013 untuk 126 perusahaan Eropa dan 282 perusahaan Amerika dan hasil penelitiannya menunjukkan bahwa OCI meningkatkan transparansi informasi berharga terkait keuntungan dan kerugian nilai wajar yang belum direalisasi yang mungkin berdampak pada operasi perusahaan sekarang dan masa depan. Berdasarkan uraian di atas dirumuskan hipotesis sebagai berikut:

H3b: Volatilitas keuntungan (kerugian) aktuaria atas program manfaat pasti berpengaruh positif terhadap volatilitas return saham. 


\section{Pengaruh Selisih kurs atas Penjabaran Laporan Keuangan Entitas Asing terhadap Volatilitas Return Saham}

Selisih kurs yang termasuk dalam komponen penghasilan komprehensif lain (OCI) adalah selisih kurs yang berasal dari transaksi pos non moneter, karena transaksi pos moneter diakui dalam laba rugi pada saat periode terjadinya transaksi tersebut. Menurut Apandi (2015) komponen OCI keuntungan dan kerugian yang timbul dari penjabaran laporan keuangan dari entitas asing dikategorikan mengandung subyektifitas yang tinggi karena membutuhkan judgment manajemen dalam menentukan functional currency yang tepat. Perusahaan yang melakukan translasi atas mata uang kemungkinan akan mengalami fluktuasi yang cukup besar dan mencerminkan risiko transaksi yang terjadi pada perusahaan, hal ini akan menjadi pusat perhatian bagi investor. Fluktuasi perubahan nilai tukar akan menimbulkan risiko dimana semakin tinggi fluktuasinya maka risikonya akan semakin besar, dan sebaliknya semakin rendah fluktuasinya maka risikonya akan semakin kecil. Risiko nilai tukar uang akan menimbulkan laba dan rugi bagi perusahaan (Shapiro, 1996).

Penelitian yang dilakukan oleh Black (2013) mengelompokkan selisih kurs penjabaran mata uang asing ke dalam kategori "accounting calculation" karena timbul dari serangkaian mekanisme aturan konsolidasi dan sebagainya. Hasil penelitannya menunjukkan bahwa volatilitas selisih kurs penjabaran mata uang asing berpengaruh positif terhadap volatilitas return saham. Chambers et al. (2007) Jurnal shaper 1196menemukan bahwa komponen OCI foreign currency and translation adjustment (selisih kurs atas penjabaran mata uang asing) merupakan komponen yang paling bermakna dibandingkan komponen OCI lainnya. Berdasarkan uraian di atas dirumuskan hipotesis sebagai berikut:

H3c: Volatilitas keuntungan (kerugian) selisih kurs atas penjabaran mata uang entitas asing berpengaruh positif terhadap volatilitas return saham.

\section{Pengaruh Keuntungan atau Kerugian dari Pengukuran Aset keuangan Tersedia untuk Dijual terhadap Volatilitas Return Saham}

Dari kelima komponen OCI, komponen keuntungan atau kerugian pengukuran kembali instrumen aset keuangan tersedia untuk dijual memiliki tingkat subjektifitas yang lebih rendah dibandingkan dengan komponen OCI lainnya karena instrumen aset keuangan memiliki kuotasi pasar aktif seperti di pasar bursa, pasar dealer, pasar pialang dan pasar antar principal (Lee dan Park, 2013). Walaupun investor bisa memantau langsung berapa nilai wajar dari item OCI ini di pasar aktif pada tanggal pelaporan keuangan, tetap saja informasi ini masih berupa unrealized bukan realized artinya informasi item OCI ini masih mengandung ketidapastian bagi investor di masa depan dan hal ini akan menjadi sebuah signal bagi investor dalam menilai tingkat risiko perusahaan dan pengambilan keputusan investasi. Risiko atas informasi item OCI aset keuangan tersedia untuk dijual akan memiliki relevansi jika terdapat reaksi yang terjadi di pasar saham.

Penelitian Black (2013) tentang relevansi risiko membagi komponen OCI dalam dua kategori yaitu fair value dan accounting calculation. Aset keuangan "tersedia untuk dijual" termasuk kedalam ketegori komponen "fair value". Hasil penelitiannya menunjukkan bahwa volatilitas keuntungan (kerugian) aset keuangan tersedia untuk dijual berpengaruh positif terhadap volatilitas return saham. Goncharov dan Hodgson (2011) menemukan bahwa instrumen aset keuangan yang tersedia untuk dijual secara signifikan memiliki nilai yang relevan. Berdasarkan uraian di atas dirumuskan hipotesis sebagai berikut:

H3d: Volatilitas keuntungan atau kerugian dari pengukuran aset keuangan tersedia untuk dijual berpengaruh positif terhadap volatilitas return saham 


\section{Pengaruh Bagian Efektif dari Keuntungan atau Kerugian Instrumen Lindung Nilai dalam rangka Lindung Nilai Arus Kas terhadap Volatilitas Return saham}

Menurut Lee dan Park (2013) komponen OCI bagian efektif dari keuntungan dan kerugian instrumen lindung nilai dalam rangka lindung nilai arus kas merupakan salah satu item OCI yang memiliki tingkat subjektifitas yang tinggi. Karena instrumen derivatif tergantung kepada nilai instrumen lainnya dan juga hubungan kontraktual, instrumen derivatif biasanya menggunakan model yang kompleks dan membutuhkan asumsi dalam pengukurannya. Penting bagi investor untuk memahami secara baik informasi yang disajikan oleh perusahaan terutama jika perusahaan melakukan transaksi derivatif. Salah satu informasi transaksi derivatif, yaitu lindung nilai terhadap kas. Dengan adanya penyajian terkait informasi ketersediaan kas, diharapkan dapat menjadi signal bagi para investor untuk menilai perusahaan tersebut, jika terdapat kemungkinan perusahaan mengalami keuntungan atau kerugian atas transaksi derivatif yang dilakukannya Hal itu akan berdampak perubahan yang terjadi di pasar saham, tingkat return yang diterima investor bisa mengalami fluktuasi (risiko pasar), sehingga dapat mempengaruhi pengambilan keputusan investasi.

Penelitian Black (2013) tentang volatilitas komponen OCI membagi komponen tersebut dalam dua kategori yaitu "fair value" dan "accounting calculation". Item OCI lindung nilai arus kas termasuk dalam kategori "fair value". Hasil penelitiannya menunjukkan bahwa volatilitas cash flow hedges memliki hubungan yang positif dengan volatilitas return saham. Berdasarkan uraian di atas dirumuskan hipotesis sebagai berikut:

H3e: Volatilitas bagian efektif keuntungan atau kerugian instrumen lindung nilai dalam rangka lindung nilai arus kas berpengaruh positif terhadap volatilitas return saham.

\section{METODE PENELITIAN}

\section{Jenis Penelitian, Populasi dan Sampel}

Jenis penelitian ini tergolong pada penelitian kuantitatif dengan melakukan analisis data berbentuk angka menggunakan data-data sekunder. Metode penelitian yang digunakan adalah penelitian asosiatif kausal. Populasi dalam penelitian ini adalah seluruh perusahaan industri keuangan dan perbankan yang terdaftar di Bursa Efek Indonesia (BEI) pada tahun 2016-2020. Sampel dari penelitian ini dilakukan dengan teknik pengambilan sampel non probability random sampling dengan jenis purposive sampling. Pemilihan sampel dalam penelitian ini dilakukan dengan menggunakan metode purposive sampling. Kriteria-kriteria yang digunakan untuk pemilihan sampel dalam penelitian ini adalah sebagai berikut :

1. Perusahaan berada pada industri keuangan dan perbankan yang terdaftar di Bursa Efek Indonesia (BEI) selama tahun 2016-2020.

2. Perusahaan yang mempublikasikan laporan keuangan kuartal untuk selama tahun 20162020.

3. Perusahaan yang memiliki data harga saham lengkap tahun 2016-2020.

4. Perusahaan yang memiliki data volatilitas return saham lebih dari nol.

5. Perusahaan yang memiliki data volatilitas laba bersih dan volatilitas laba komprehensif lebih dari nol.

6. Perusahaan yang memiliki volatilitas masing-masing komponen OCI lebih dari nol.

7. Perusahaan yang memiliki data yang berkaitan dengan variabel-variabel penelitian.

Berdasarkan pada kriteria diatas, maka sampel yang digunakan dalam penelitian ini dapat dilihat dari tabel berikut ini : 
Tabel 1

Kriteria Pemilihan Sampel Model 1 dan Model 2

\begin{tabular}{|c|c|c|c|c|c|c|}
\hline \multirow{2}{*}{ No } & \multirow{2}{*}{ Keterangan } & \multicolumn{5}{|c|}{ Jumlah Sampel } \\
\hline & & 2016 & 2017 & 2018 & 2019 & 2020 \\
\hline 1 & Seluruh perusahaan keuangan terdaftar di BEI & 89 & 90 & 91 & 90 & 94 \\
\hline 2 & $\begin{array}{l}\text { Perusahaan yang tidak memiliki laporan keuangan } \\
\text { kuartal lengkap }\end{array}$ & 0 & $(2)$ & $(5)$ & (2) & $(5)$ \\
\hline 3 & $\begin{array}{l}\text { Perusahaan yang tidak memiliki data harga saham } \\
\text { lengkap }\end{array}$ & $(8)$ & $(6)$ & (6) & (3) & (2) \\
\hline 4 & $\begin{array}{l}\text { Perusahaan yang memiliki nilai volatiliitas return } \\
\text { saham sama dengan nol }\end{array}$ & (2) & (1) & $(1)$ & (2) & (3) \\
\hline 5 & $\begin{array}{l}\text { Perusahaan yang memiliki nilai volatiliitas laba } \\
\text { bersih sama dengan nol }\end{array}$ & 0 & 0 & 0 & 0 & 0 \\
\hline 6 & $\begin{array}{l}\text { Perusahaan yang memiliki nilai volatilitas laba } \\
\text { komprehensif sama dengan nol }\end{array}$ & 0 & 0 & 0 & 0 & 0 \\
\hline \multicolumn{2}{|r|}{ Total Sampel Penelitian (Model 1 dan Model 2) } & 79 & 81 & $\begin{array}{c}79 \\
406\end{array}$ & 83 & 84 \\
\hline
\end{tabular}

Tabel 2

Kriteria Pemilihan Sampel Model 3

\begin{tabular}{|c|c|c|c|c|c|c|c|}
\hline Model & Keterangan & 2016 & 2017 & 2018 & 2019 & 2020 & Jumlah \\
\hline $3 a$ & $\begin{array}{l}\text { Volatilitas Perubahan dalam surplus } \\
\text { revaluasi }\end{array}$ & 27 & 19 & 28 & 24 & 24 & 122 \\
\hline $3 b$ & $\begin{array}{l}\text { Volatilitas Keuntungan atau kerugian } \\
\text { aktuarial atas program manfaat pasti }\end{array}$ & 77 & 79 & 76 & 81 & 82 & 395 \\
\hline $3 c$ & $\begin{array}{l}\text { Volatilitas Keuntungan dan kerugian yang } \\
\text { timbul dari selisih kurs penjabaran laporan } \\
\text { keuangan }\end{array}$ & 6 & 6 & 6 & 7 & 7 & 32 \\
\hline $3 d$ & $\begin{array}{l}\text { Volatilitas Keuntungan atau kerugian dari } \\
\text { pengukuran kembali aset keuangan tersedia } \\
\text { untuk dijual }\end{array}$ & 49 & 53 & 60 & 61 & 61 & 284 \\
\hline $3 e$ & $\begin{array}{l}\text { Volatilitas Bagian efektif dari keuntungan } \\
\text { dan kerugian instrumen lindung nilai dalam } \\
\text { rangka lindung nilai arus kas }\end{array}$ & 6 & 7 & 7 & 9 & 11 & 40 \\
\hline
\end{tabular}

Sumber: Data olahan peneliti (2021)

\section{Jenis, Sumber dan Teknik Pengumpulan Data}

Penelitian ini menggunakan jenis data sekunder berupa laporan keuangan kuartal perusahaan industri keuangan dan perbankan yang terdaftar di Bursa Efek Indonesia tahun 2016-2020 dan data harga penutupan saham (closing price). Sumber data sekunder yang digunakan diperoleh melalui website www.idx.co.id dan website perusahaan bersangkutan, sedangkan harga penutupan saham dari dari situs www.yahoofinance.com. Teknik pengumpulan data menggunkan teknik obeservasi dokumentasi dengan melakukan investigasi terhadap laporan keuangan perushaaan industri keuangan dan perbankan yang telah terdaftar dan dipublikasikan dari tahun 2016-2020 serta mempelajari literatur yang berkaitan dengan permasalahan penelitian yang dijelaskan.

\section{Variabel Penelitian dan Pengukuran Variabel Dependen}

Variabel dependen dalam penelitian ini adalah volatilitas return saham (stock return volatility). Volatilitas return saham merupakan proksi dari dari standar deviasi $(\sigma)$ dari return bulanan yang disetahunkan seperti yang telah digunakan dalm peneltiitan Khan dan Bradbury (2014). Pengukuran volatilitas return saham dihitung berdasarkan hasil standar deviasi return 
saham bulanan yang dikalikan dengan $\sqrt{ } 12$ untuk menghindari bias. Standar deviasi berdasarkan data return harian, mingguan, bulanan dan kuartal dapat disetahunkan dengan mengalikan data standar deviasi tersebut dengan akar kuadrat (square root) dari jumlah data return harian, mingguan, bulanan atau kuartal sehingga menjadi standar deviasi disetahunkan atau volatilitas tahunan ( $\underline{\text { www.wallstreetmojo.com}}$ ). Tahapan untuk mengukur volatilitas return saham yaitu sebagai berikut :

\section{Tabel 3}

Mengukur volatilitas return saham

\begin{tabular}{cccc}
\hline $\begin{array}{c}\text { Variabel } \\
\text { Dependen }\end{array}$ & Langkah 1 & Langkah 2 & Langkah 3 \\
\hline $\begin{array}{c}\text { Volatilitas } \\
\text { Return } \\
\text { Saham }\end{array}$ & Menghitung Return & Menghitung Volatilitas & Volatilitas Disetahunkan $_{i t}=\frac{\mathrm{P}_{i t}-\mathrm{P}_{i t-1}}{\mathrm{P}_{i t-1}}$ \\
$\operatorname{Ret}_{i t}=\sqrt{\sum \frac{\left(\operatorname{Ret}_{i t}-\operatorname{Ret}_{i t}\right)^{2}}{\mathrm{n}-1}}$ & $\sigma$ AnnualRet $_{i t}=\sigma \operatorname{Ret}_{i t} \times \sqrt{\mathrm{n}}$ \\
\hline
\end{tabular}

Keterangan :

\begin{tabular}{|c|c|}
\hline $\operatorname{Ret}_{i t}$ & : Return saham perusahaan $i$ pada periode $t$. \\
\hline $\mathrm{P}_{i t}$ & : Harga saham perusahaan $i$ pada periode $t$. \\
\hline $\mathrm{P}_{i t-1}$ & : Harga saham perusahaan $i$ pada periode $\mathrm{t}-1$. \\
\hline$\sigma$ Ret $_{i t}$ & : Standar deviasi return saham perusahaan $i$ pada tahun $t$. \\
\hline $\operatorname{Ret}_{i t}$ & : Return saham perusahaan $i$ pada periode $t$. \\
\hline $\begin{array}{l}\operatorname{Ret}_{i t} \\
\mathrm{n}\end{array}$ & $\begin{array}{l}\text { : Rata-rata return saham perusahaan } i \text { pada tahun } t \text {. } \\
\text { : Jumlah periode (waktu). }\end{array}$ \\
\hline $\begin{array}{r}\sigma \text { AnnualRet }_{i t} \\
\text { tahun } t .\end{array}$ & : Standar deviasi return saham disetahunkan perusahaan $i$ pada \\
\hline$\sigma \operatorname{Ret}_{i t}$ & : Standar deviasi return saham perusahaan $i$ pada tahun $t$. \\
\hline$\sqrt{n}$ & Akar kuadrat jumlah periode (waktu). \\
\hline
\end{tabular}

\section{Variabel Independen}

Variabel independen pertama yaitu volatilitas laba bersih. Pengukuran volatilitas laba bersih pada penelitian ini mengadopsi dari penelitian yang dilakukan oleh Khan dan Bradbury (2014). Volatilitas laba bersih pada penelitian ini diukur dengan standar deviasi $(\sigma)$ laba bersih dibagi dengan nilai pasar perusahaan dan kemudian disetahunkan dengan dikali akar kuadrat (square root) $\sqrt{ } 4$. Akar kuadarat (square root) $\sqrt{4}$ digunakan karena laba bersih yang digunakan berasal dari data laporan keuangan kuartal. Langkah perhitungan volatilitas laba bersih adalah sebagai berikut :

Tabel 4

mengukur volatilitas laba bersih

\begin{tabular}{cc}
\hline Variabel Independen & Volatilitas Laba Bersih \\
\hline Langkah 1 & $\mathrm{NI}_{i t}=\frac{\text { Laba Bersih perusahaan } i \text { pada kuartal } t}{\text { Nilai Pasar Perusahaan } i \text { pada pada tahun } t} \times 100 \%$ \\
Rasio & $\sigma \mathrm{NI}_{i t}=\sqrt{\sum \frac{\left(\mathrm{NI}_{i t}-\mathrm{NI}_{i t}\right)^{2}}{\mathrm{n}-1}}$ \\
Langkah 2 & \\
Volatilitas & \\
Langkah 3 & $\sigma$ AnnualNI $_{\mathrm{it}}=\sigma \mathrm{NI}_{\mathrm{it}} \mathrm{x} \sqrt{\mathrm{n}}$ \\
Volatilitas Disetahunkan &
\end{tabular}
Keterangan :

$\begin{array}{ll}\sigma \mathrm{NI}_{i t} & : \text { Standar deviasi laba bersih perusahaan } i \text { pada tahun } t . \\ \mathrm{NI}_{i t} & : \text { Laba bersih perusahaan } i \text { pada tahun } t . \\ \mathrm{NI}_{i t} & : \text { Rata-rata laba bersih perusahaan } i \text { pada tahun } t . \\ \mathrm{n} & : \text { Jumlah periode (waktu). } \\ \sigma \mathrm{AnnualNI}_{\mathrm{it}} & : \text { Standar deviasi laba bersih disetahunkan perusahaan } i \text { pada tahun } t . \\ \sigma \mathrm{NI}_{\text {it }} & : \text { Standar deviasi laba bersih perusahaan } i \text { pada tahun } t . \\ \sqrt{\mathrm{n}} & : \text { Akar kuadrat jumlah periode (waktu) }\end{array}$


Variabel independen kedua yaitu volatilitas laba komprehensif. Pengukuran volatilitas laba komprehensif sama dengan pengukuran volatilitas laba bersih yaitu mengadopsi dari penelitian yang dilakukan oleh Khan dan Bradbury (2014). Langkah perhitungan volatilitas laba bersih dan volatilitas laba komprehensif adalah sebagai berikut :

Tabel 5

volatilitas laba komprehensif

\begin{tabular}{cc}
\hline Variabel Independen & Volatilitas Laba Komprehensif \\
\hline Langkah 1 & $\mathrm{CI}_{i t}=\frac{\text { Laba Komprehensif perusahaan } i \text { pada kuartal } t}{\text { Nilai Pasar Perusahaan } i \text { pada pada tahun } t} \times 100 \%$ \\
Rasio & $\sigma \mathrm{CI}_{i t}=\sqrt{\sum \frac{\left(\mathrm{CI}_{i t}-\mathrm{CI}_{i t}\right)^{2}}{\mathrm{n}-1}}$ \\
Langkah 2 & \\
Volatilitas & \\
Langkah 3 & $\sigma$ AnnualCI $_{\mathrm{it}}=\sigma \mathrm{CI}_{\mathrm{it}} \mathrm{x} \sqrt{\mathrm{n}}$ \\
Volatilitas Disetahunkan &
\end{tabular}
Keterangan :

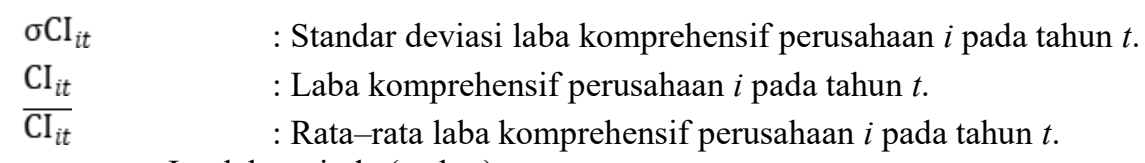

$\mathrm{n} \quad$ : Jumlah periode (waktu).

$\sigma$ AnnualCI $_{\text {it }} \quad$ : Standar deviasi laba komprehensif disetahunkan perusahaan $i$ pada $\mathrm{t}$ tahun $t$.

$\sigma \mathrm{CI}_{\mathrm{it}} \quad:$ Standar deviasi laba komprehensif perusahaan $i$ pada tahun $t$.

$\sqrt{\mathrm{n}} \quad:$ Akar kuadrat jumlah periode (waktu)

\section{Volatilitas Komponen-Komponen Penghasilan Komprehensif Lain (OCI)}

Pengukuran volatilitas komponen-komponen OCI mengadopsi dari penelitian yang dilakukan oleh Khan dan Bradbury (2014). Volatilitas komponen-komponen OCI diukur dengan standar deviasi $(\sigma)$ komponen-komponen OCI yang dibagi dengan nilai pasar perusahaan dan kemudian disetahunkan dengan dikali akar kuadrat (square root) $\sqrt{ } 4$. Akar kuadarat (square root) $\sqrt{4}$ digunakan karena nilai dari komponen-komponen OCI yang digunakan berasal dari data laporan keuangan kuartal. Langkah perhitungannya adalah sebagai berikut :

Tabel 6

Pengukuran volatilitas komponen-komponen OCI

\begin{tabular}{|c|c|c|c|c|}
\hline $\begin{array}{c}\text { Mode } \\
1\end{array}$ & $\begin{array}{c}\text { Variabe } \\
1 \\
\text { Indepen } \\
\text { den } \\
\end{array}$ & $\begin{array}{c}\text { Langkah } 1 \\
\text { Menghitung Rasio }\end{array}$ & $\begin{array}{c}\text { Langkah } 2 \\
\text { Menghitung Volatilitas }\end{array}$ & $\begin{array}{c}\text { Langkah } 3 \\
\text { Volatilitas Disetahunkan }\end{array}$ \\
\hline $3 a$ & SR & $\mathrm{SR}_{i t}=\frac{\mathrm{SR}_{i t}}{\mathrm{MV}_{i t}} \times 100 \%$ & $\Sigma \mathrm{SR}_{i t}=\sqrt{\sum \frac{\left(\mathrm{SR}_{i t}-\mathrm{SR}_{i t}\right)^{2}}{\mathrm{n}-1}}$ & $\sigma$ AnnualSR $_{\text {it }}=\sigma S R_{\text {it }} \times \sqrt{n}$ \\
\hline $3 b$ & PMP & $\mathrm{PMP}_{i t}=\frac{\mathrm{PMP}_{i t}}{\mathrm{MV}_{i t}} \times 100 \%$ & $\Sigma \mathrm{PMP}_{i t}=\sqrt{\sum \frac{\left(\mathrm{PMP}_{i t}-\mathrm{SR}_{i t}\right)^{2}}{\mathrm{n}-1}}$ & $\begin{array}{l}\sigma \text { AnnualPMP }_{\text {it }}= \\
\sigma \mathrm{PMP}_{\text {it }} \times \sqrt{\mathrm{n}}\end{array}$ \\
\hline $3 c$ & KURS & $\begin{array}{l}\mathrm{KURS}_{i t}= \\
\frac{\mathrm{KURS}_{i t}}{\mathrm{MV}_{i t}} \times 100 \%\end{array}$ & $\begin{array}{l}\Sigma \mathrm{KURS}_{i t}= \\
\sqrt{\sum \frac{\left(\mathrm{KURS}_{i t}-\mathrm{SR}_{i t}\right)^{2}}{\mathrm{n}-1}}\end{array}$ & $\sigma$ AnnualKURS $_{\text {it }}=\sigma \mathrm{KURS}_{\mathrm{it}} \mathrm{x} \sqrt{ }$ \\
\hline $3 d$ & AFS & $\mathrm{AFS}=\frac{\mathrm{AFS}_{i t}}{\mathrm{MV}_{i t}} \times 100 \%$ & $\Sigma \mathrm{AFS}_{i t}=\sqrt{\sum \frac{\left(\mathrm{AFS}_{i t}-\mathrm{SR}_{i t}\right)^{2}}{\mathrm{n}-1}}$ & $\begin{array}{l}\sigma \text { AnnualAFS }_{\text {it }}= \\
\sigma \mathrm{AFS}_{\mathrm{it}} \times \sqrt{\mathrm{n}}\end{array}$ \\
\hline
\end{tabular}




$$
\text { 3e HED } \quad \mathrm{DER}_{i t}=\frac{\mathrm{DER}_{i t}}{\mathrm{MV}_{i t}} \times 100 \% \quad \Sigma \mathrm{DER}_{i t}=\sqrt{\sum \frac{\left(\mathrm{DER}_{i t}-\mathrm{SR}_{i t}\right)^{2}}{\mathrm{n}-1}} \begin{aligned}
& \sigma \mathrm{AnnualDER}_{\mathrm{it}}= \\
& \sigma \mathrm{DER}_{\mathrm{it}} \mathrm{x} \sqrt{\mathrm{n}}
\end{aligned}
$$

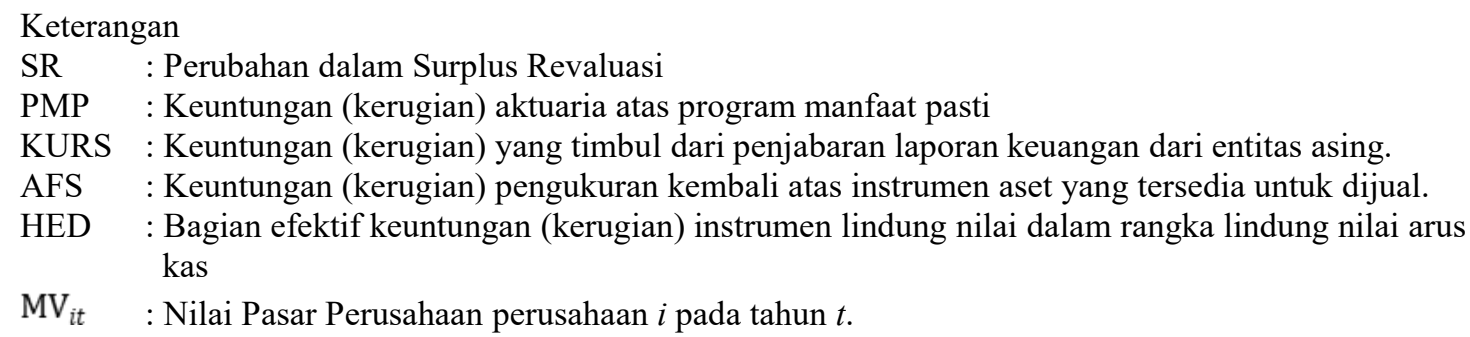

\section{Metode Analisis Data}

Uji Statistik Deskriptif

Pengujian statistik deskriptif pada penelitian ini digunakan untuk memberikan gambaran distribusi, nilai rata-rata (mean), standard deviasi, maksimum, dan minimum pada masingmasing

variabel penelitian.

\section{Uji Asumsi Klasik}

Dalam proses pengujian hipotesis penelitian, suatu model regresi harus memenuhi asumsi klasik. Uji asumsi klasik yang digunakan dalam penelitian ini adalah: uji normalitas, uji autokorelasi, dan uji heteroskedastisitas. Menurut Nazaruddin dan Basuki (2015) uji asumsi klasik merupakan persyaratan statistik yang harus dipenuhi apabila menggunakan analisis regresi.

\section{Uji Hipotesis}

Pengujian hipotesis pada penelitian ini menggunakan uji regresi linear sederhana. Adapun persamaan analisis regresi masing-masing model yang digunakan untuk pengujian hipotesis adalah sebagai berikut :

\section{Model 1 untuk menguji Hipotesis 1}

Pengujian hipotesis $1\left(\mathrm{H}_{1}\right)$ dapat dilakukan dengan model persamaan berikut ini :

VRet $_{\text {it }+1}=\beta+\beta_{1}$ VNI $_{\text {it }}+\mathbf{e}$

Keterangan :

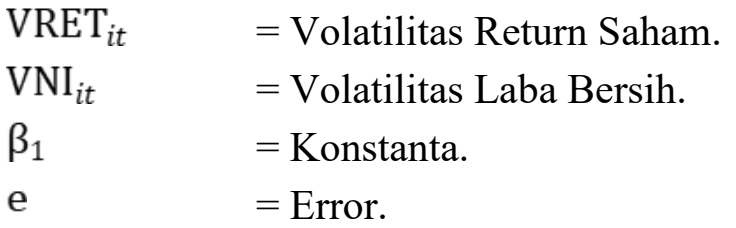

\section{Model 2 untuk menguji Hipotesis 2}

Pengujian hipotesis $2\left(\mathrm{H}_{2}\right)$ dapat dilakukan dengan model persamaan berikut ini :

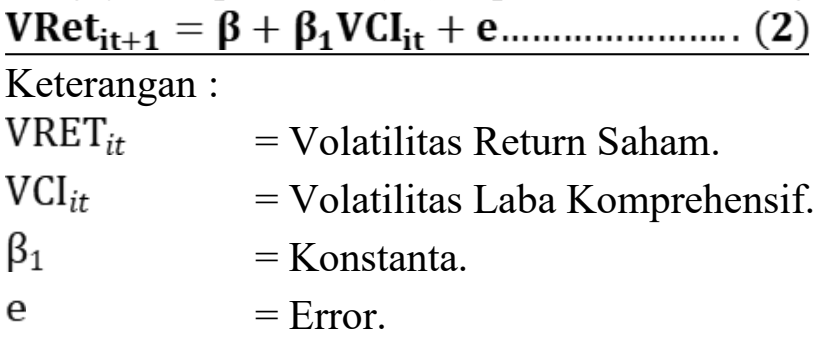




\section{Model 3 untuk menguji Hipotesis 3}

Pengujian hipotesis $3\left(\mathrm{H}_{3}\right)$ dibagi menjadi 5 jenis model karena bertujuan untuk menguji masing-masing komponen OCI yang terbagi menjadi 5 jenis komponen. Adapun model persamaan yang digunakan adalah sebagai berikut :

\begin{tabular}{|c|}
\hline 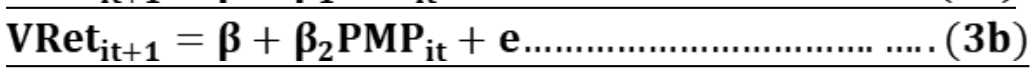 \\
\hline 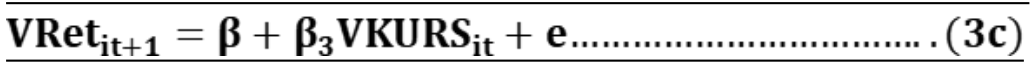 \\
\hline 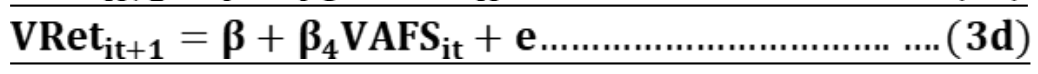 \\
\hline 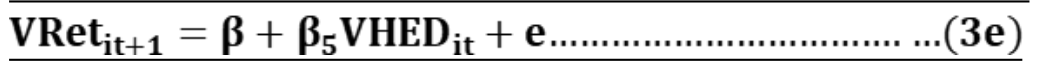 \\
\hline
\end{tabular}

\section{Keterangan :}

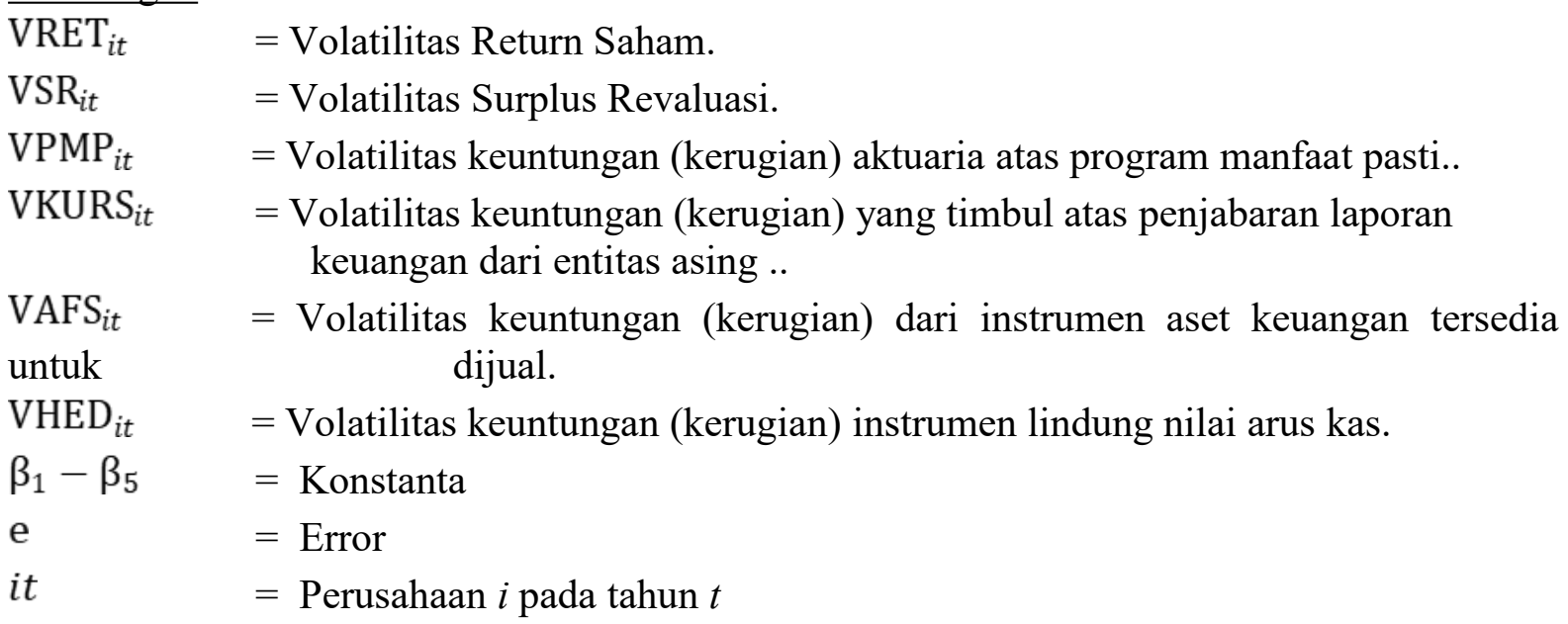

\section{Uji Koefisien Daterminasi (Adjusted $\boldsymbol{R}^{2}$ )}

Koefisien determinasi digunakan untuk mengukur seberapa besar variasi dari variabel dependen dapat dijelaskan oleh variasi dari nilai variabel independen. Nilai koefisien determinasi (Adjusted $R 2$ ) yaitu antara 0 dan 1 . Semakin dekat dengan nilai satu maka hal tersebut berarti variabel independen dapat menjelaskan informasi yang dibutuhkan untuk memprediksi variabel dependen (Ghozali, 2013).

HASIL DAN PEMBAHASAN

\section{Uji Statistik Deskriptif}

Tabel 7

Hasil Uji Statistik Deskriptif

\begin{tabular}{|c|c|c|c|c|c|c|}
\hline Variabel & Model & $\mathbf{N}$ & Minimum & Maksimum & Nilai Mean & Std. Deviasi \\
\hline \multirow{7}{*}{ VRET } & 1 & 380 & $-1,07712$ & 0,20351 & $-0,452720$ & 0,26191055 \\
\hline & 2 & 380 & $-1,07712$ & 0,20351 & -04491033 & 0,26187817 \\
\hline & $3 a$ & 119 & $-1,29286$ & 0,59754 & $-0,4615999$ & 0,29537699 \\
\hline & $3 b$ & 366 & $-1,04412$ & 0,16773 & $-0,4493096$ & 0,25915013 \\
\hline & $3 \mathrm{c}$ & 32 & $-0,99551$ & $-0,13500$ & $-0,5612578$ & 0,23890942 \\
\hline & $3 d$ & 276 & $-1,34602$ & 0,99912 & $-0,4363461$ & 0,31020470 \\
\hline & $3 e$ & 39 & $-0,91916$ & 1,17941 & $-0,3474144$ & 0,39527792 \\
\hline VNI & 1 & 380 & $-5,00000$ & 0,07788 & $-1,3926052$ & 0,59646862 \\
\hline VCI & 2 & 380 & $-5,00000$ & 0,98236 & $-1,2955958$ & 0,61560301 \\
\hline VSR & $3 a$ & 119 & $-5,00000$ & 0,17688 & $-2,2231731$ & 1,04772194 \\
\hline VPMP & $3 b$ & 366 & $-5,00000$ & $-0,92460$ & $-2,7639615$ & 0,71956209 \\
\hline VKURS & $3 \mathrm{c}$ & 32 & $-5,00000$ & $-0,38457$ & $-3,7704222$ & 1,00243339 \\
\hline VAFS & $3 d$ & 276 & $-5,00000$ & 0,16913 & $-2,1791934$ & 0,84287974 \\
\hline VHED & $3 e$ & 39 & $-4,22185$ & $-0,87893$ & $-2,4136564$ & 0,87097545 \\
\hline
\end{tabular}


Hasil statistik deskriptif menampilkan nilai minimum, nilai maksimum, rata-rata dan standar deviasi dari masing-masing variabel. Variabel VRET pada model 1-3e memiliki nilai minimum berkisar antara $-1,34602$ dan $-0,91916$, nilai maksimum model 1-3e berkisar antara $-0,13500$ dan 1,17941 dengan nilai rata-rata model 1-3e berkisar antara $-0,5612578$ dan 0,3474144 dan standar deviasi model 1-3e berkisar antara 0,23890942 dan 0,39527792. Variabel VNI memiliki nilai minimum -5,00000 dan nilai maksimum 0,07788 dengan nilai rata-rata $-1,3926052$ dan standar deviasi 0,59646862. Variabel VCI memiliki nilai miniumum $-5,00000$ dan nilai maksimum 0,98236 dengan nilai rata-rata $-1,2955958$ dan standar deviasi sebesar 0,61560301. Variabel VSR memiliki nilai miniumum -5,00000 dan nilai maksimum 0,17688 dengan nilai rata-rata $-2,2231731$ dan standar deviasi sebesar 1,04772194. Variabel VPMP memiliki nilai miniumum -5,00000 dan nilai maksimum -0,92460 dengan nilai ratarata $-2,7639615$ dan standar deviasi 0,71956209. Variabel VKURS memiliki nilai miniumum $-5,00000$ dan nilai maksimum -0,38457 dengan nilai rata-rata $-3,7704222$ dan standar deviasi 1.00243339. Variabel VAFS memiliki nilai miniumum $-5,00000$ dan nilai maksimum 0,16913 dengan nilai rata-rata $-2,1791934$ dan standar deviasi 0,84287974 . Variabel VHED memiliki nilai miniumum $-4,22185$ dan nilai maksimum sebesar $-0,87893$ dengan nilai ratarata $-2,4136564$ dan standar deviasi sebesar 0,87097445 .

\section{Uji Koefisien Daterminasi (Adjusted $R^{2}$ ) dan Uji Hipotesis}

Tabel 8

Hasil Uji Koefisien Determinasi (Adjusted $\boldsymbol{R}^{2}$ )

\begin{tabular}{ccccc}
\hline Model & R & R Square & Adjusted R square & Std. Error of the Estimate \\
\hline 1 & $.050^{\mathrm{a}}$ & .003 & .000 & .26192393 \\
2 & $.034^{\mathrm{a}}$ & .001 & -.001 & .26207429 \\
$3 \mathrm{a}$ & $.007^{\mathrm{a}}$ & .000 & -.009 & .29663004 \\
$3 \mathrm{~b}$ & $.059^{\mathrm{a}}$ & .004 & .001 & .25905113 \\
$3 \mathrm{c}$ & $.307^{\mathrm{a}}$ & .094 & .064 & .23114263 \\
$3 \mathrm{~d}$ & $.055^{\mathrm{a}}$ & .003 & -.001 & .31030203 \\
$3 \mathrm{e}$ & $.506^{\mathrm{a}}$ & .256 & .236 & .34554585 \\
\hline
\end{tabular}

Sumber : Hasil olah data statistik 2021 (SPSS 23).

Pada Tabel 8 dapat diketahui koefisien determinasi yang dilihat dari Adjusted $R^{2}$. Pada model 1 nilai adjusted $R^{2}$ sebesar 0,000 (0\%) yang artinya variabel VNI tidak mampu menjelaskan variabel dependennya yaitu volatilitas return saham. Pada model 2 nilai adjusted $R^{2}$ sebesar $-0,001(-0,1 \%)$. Nilai adjusted $R^{2}$ yang minus dianggap 0 , artinya variabel VCI tidak mampu menerangkan variabel dependen volatilitas return saham. Pada model 3a nilai adjusted $R^{2}$ sebesar $-0,009(-0,9 \%)$. Nilai adjusted $R^{2}$ yang minus dianggap 0 , artinya variabel VSR tidak mampu menerangkan variabel dependen volatilitas return saham. Pada model $3 \mathrm{~b}$ nilai adjusted $R^{2}$ sebesar $0,001(0,1 \%)$ yang artinya variabel VPMP mampu menjelaskan variabel dependennya yaitu volatilitas return saham sebesar $0,001(0,01 \%)$. Pada model $3 \mathrm{c}$ nilai adjusted $R^{2}$ sebesar $0,064(6,4 \%)$ yang artinya variabel VKURS mampu menjelaskan variabel dependennya yaitu volatilitas return saham sebesar $0,001(6,4 \%)$. Pada model $3 \mathrm{~d}$ nilai adjusted $R^{2}$ sebesar $-0,001(-0,1 \%)$. Nilai adjusted $R^{2}$ yang minus dianggap 0 , artinya variabel VAFS tidak mampu menerangkan variabel dependen volatilitas return saham. Pada model 3e nilai adjusted $R^{2}$ sebesar $0,236(23,6 \%)$ yang artinya variabel VHED mampu menjelaskan variabel dependennya volatilitas return saham yaitu sebesar $0,236(23,6 \%)$. 
Tabel 9

Hasil Pengujian Hipotesis 1

\begin{tabular}{|c|c|c|c|c|c|c|}
\hline \multirow{2}{*}{\multicolumn{2}{|c|}{ Model }} & \multicolumn{2}{|c|}{ Unstandardized Coefficients } & \multicolumn{2}{|l|}{$\begin{array}{l}\text { Standardized } \\
\text { Coefficients }\end{array}$} & \multirow[b]{2}{*}{ Sig. } \\
\hline & & $\mathrm{B}$ & Std. Error & Beta & $\mathrm{T}$ & \\
\hline 1 & $\begin{array}{c}\text { (Constant) } \\
\text { VNI }\end{array}$ & $\begin{array}{r}-.422 \\
022\end{array}$ & $\begin{array}{l}.034 \\
023\end{array}$ & 050 & $\begin{array}{c}-12.339 \\
980\end{array}$ & $\begin{array}{l}.000 \\
327\end{array}$ \\
\hline
\end{tabular}

a. Dependent Variable: VRET

Sumber : Hasil olah data statistik 2021 (SPSS 23).

Variabel volatilitas laba bersih memiliki nilai koefisien regresi sebesar 0,022 dengan signifikansi $0,327>$ alpha 0,05 atau $5 \%$ sehingga volatilitas laba bersih tidak berpengaruh positif terhadap volatilitas return saham. Dengan demikin, hipotesis 1 tidak didukung.

Tabel 10

Hasil Pengujian Hipotesis 2

\begin{tabular}{|c|c|c|c|c|c|c|}
\hline \multirow{2}{*}{\multicolumn{2}{|c|}{ Model }} & \multicolumn{2}{|c|}{ Unstandardized Coefficients } & \multirow[t]{2}{*}{$\begin{array}{c}\text { Standardized } \\
\text { Coefficients } \\
\text { Beta }\end{array}$} & \multirow[b]{2}{*}{$\mathrm{t}$} & \multirow[b]{2}{*}{ Sig. } \\
\hline & & B & Std. Error & & & \\
\hline 1 & (Constant) & -.430 & .031 & & -13.727 & .000 \\
\hline & $\mathrm{VCI}$ & .014 & .022 & .034 & .658 & .511 \\
\hline
\end{tabular}

a. Dependent Variable: VRET

Sumber : Hasil olah data statistik 2021 (SPSS 23).

Variabel volatilitas laba komprehensif memiliki nilai koefisien regresi sebesar 0,014 dengan signifikansi $0,511>$ alpha 0,05 atau $5 \%$ sehingga volatilitas laba komprehensif tidak berpengaruh positif terhadap volatilitas return saham. Dengan demikin, hipotesis 2 tidak didukung.

Tabel 11

Hasil Pengujian Hipotesis 3

\begin{tabular}{|c|c|c|c|c|c|c|}
\hline \multirow[b]{2}{*}{ Mod } & & \multicolumn{2}{|c|}{ Unstandardized Coefficients } & \multicolumn{3}{|l|}{$\begin{array}{l}\text { Standardized } \\
\text { Coefficients }\end{array}$} \\
\hline & & B & Std. Error & Beta & $\mathrm{t}$ & Sig. \\
\hline \multirow[t]{2}{*}{$3 a$} & (Constant) & -.466 & .064 & & -7.277 & .000 \\
\hline & VSR & -.002 & .026 & -.007 & -.072 & .943 \\
\hline \multirow[t]{2}{*}{$3 b$} & (Constant) & -.508 & .054 & & -9.444 & .000 \\
\hline & VPMP & -.021 & .019 & -.059 & -1.131 & .259 \\
\hline \multirow[t]{2}{*}{$3 \mathrm{c}$} & (Constant) & -.286 & .161 & & -1.769 & .087 \\
\hline & VKURS & .073 & .041 & .307 & 1.766 & .088 \\
\hline \multirow[t]{2}{*}{$3 d$} & (Constant) & -.392 & .052 & & -7.566 & .000 \\
\hline & VAFS & .020 & .022 & .055 & .910 & .364 \\
\hline \multirow[t]{2}{*}{$3 e$} & (Constant) & .207 & .165 & & 1.254 & .218 \\
\hline & VHED & .230 & .064 & .506 & 3.567 & .001 \\
\hline
\end{tabular}

Berdasarkan Tabel 11 variabel VSR memiliki nilai koefisien regresi sebesar -0,002 dengan signifikansi $0,943>$ alpha 0,05 atau 5\% sehingga volatilitas surplus revaluasi tidak berpengaruh positif terhadap volatilitas return saham. Dengan demikin, hipotesis 3a tidak didukung.

Variabel VPMP memiliki nilai koefisien regresi sebesar -0,002 dengan signifikansi $0,943>$ alpha 0,05 atau $5 \%$ sehingga volatilitas surplus revaluasi tidak berpengaruh positif terhadap volatilitas return saham. Dengan demikin, hipotesis $3 \mathrm{~b}$ tidak didukung. 
Variabel VKURS memiliki nilai koefisien regresi sebesar -0,073 dengan signifikansi 0,088>alpha 0,05 atau 5\% sehingga volatilitas Selisih kurs tidak berpengaruh positif terhadap volatilitas return saham. Dengan demikin, hipotesis $3 \mathrm{c}$ tidak didukung.

Variabel VAFS memiliki nilai koefisien regresi sebesar 0,020 dengan signifikansi $0,364>$ alpha 0,05 atau 5\% sehingga volatilitas aset keuangan tersedia untuk dijual tidak berpengaruh positif terhadap volatilitas return saham. Dengan demikin, hipotesis $3 \mathrm{~d}$ tidak didukung.

Variabel VHED memiliki nilai koefisien regresi sebesar 2,230 dengan signifikansi $0,001>$ alpha 0,05 atau 5\% sehingga volatilitas lindung nilai arus kas tidk berpengaruh positif terhadap volatilitas return saham. Dengan demikin, hipotesis 3e didukung.

\section{Pembahasan}

\section{Pengaruh Volatilitas Laba Bersih terhadap Volatilitas Return Saham}

Hasil pengujian hipotesis pertama yang menyatakan bahwa volatilitas laba bersih berpengaruh terhadap volatilitas return saham tidak dapat dibuktikan secara statistik. Hal ini berarti bahwa volatilitas laba bersih tidak memiliki relevansi risiko bagi investor dalam pengambilan keputusan investasi. Kinerja perusahaan saat ini tidak hanya dilihat hanya dilihat dari laba bersih namun ada ukuran yaitu laba komprehensif. Berbeda dengan laba bersih, laba komprehensif mencerminkan perubahan nilai pasar dan kondisi perekonomian. Perubahan ini muncul dengan OCI yang menjadi bagian dari laba komprehensif lain. Dibandingkan laba bersih, laba komprehensif terlihat lebih berisiko dengan adanya item-item bersifat unrealized gains or losses yang sangat dipengaruhi oleh kondisi pasar. Oleh karena itu, sejalan dengan teori signalling, bahwa informasi yang diterbitkan oleh pihak manajemen perusahaan akan memberikan signal bagi investor untuk pengambilan keputusan. Dengan demikian, informasi laba bersih menjadi kurang relevan bagi investor dalam menilai kinerja serta risiko perusahaan karena adanya informasi baru seperti laba komprehensif.

Hasil penelitian diatas konsisten dengan penelitian yang dilakukan oleh Kouki et al. (2016) yang menyatakan bahwa volatilitas laba bersih tidak berpengaruh terhadap volatilitas return saham. Hasil ini juga sejalan dengan penelitian yang dilkukan oleh Rusdiyanto (2019) yang menemukan bahwa volatilitas laba bukan merupakan informasi yang relevan bagi investor. Dalam hal ini, volatilitas return saham belum bisa terefleksikan dengan baik oleh informasi yang terdapat dalam volatilitas laba bersih, artinya ada informasi lain yang mempunyai relevansi risiko yang mempengaruhi tingkat volatilitas return saham yang ditanggung oleh investor. Temuan ini tidak konsisten dengan dengan hasil penelitian yang dilakukan oleh Khan dan Bradbury (2014) yang menyatakan bahwa volatilitas laba bersih berpengaruh positif terhadap volatilitas return saham.

\section{Pengaruh Volatilitas Laba Komprehensif terhadap Volatilitas Return Saham}

Hasil pengujian hipotesis kedua yang menyatakan bahwa volatilitas laba komprehensif berpengaruh terhadap volatilitas return saham tidak dapat dibuktikan secara statistik. Hal ini berarti bahwa volatilitas laba komprehensif tidak memiliki relevansi risiko bagi investor dalam pengambilan keputusan investasi. Investor tidak melihat bahwa volatilitas laba komprehensif sebagai risiko dari kinerja perusahaan. Adanya kemungkinan informasi terkait laba komprehensif memiliki kerumitan dalam pemahamannya. Informasi laba komprehensif tidak hanya terdiri dari laba bersih namun juga OCI dimana komponenkomponen OCI menunjukkan informasi yang membutuhkan pemahaman yang lebih jauh karena adanya penggunan asumsi, judgement, dan estimasi oleh manajemen perusahaan. Dalam hal ini, terutama investor di Indonesia masih memandang laba bersih sebagai ukuran kinerja perusahaan, karena laba komprehensif baru mendapat perhatian setelah implementasi 
PSAK tahun 2012. Sehingga investor beranggapan bahwa informasi volatilitas laba komprehensif bukan merupakan risiko yang harus dicermati dalam rangka pengambilan keputusan investasi.

Hasil penelitian diatas konsisten dengan penelitian yang dilakukan oleh Kouki et al. (2016) yang juga tidak dapat membuktikan bahwa volatilitas laba komprehensif berpengaruh positif terhadap volatilitas return saham. Hasil penelitian Rusdiyanto (2019) menemukan hal yang sama bahwa laba komprehensif bukan merupakan informasi yang relevan bagi investor dalam peniliaian investasi yang mereka lakukan. Dalam hal ini, para investor masih membutuhkan waktu untuk menyesuaikan diri dengan informasi baru terkait kinerja keuangan yaitu laba komprehensif, sehingga investor belum menilai laba komprehensf sebagai risiko informasi dalam proses pengambilan keputusan investasi yang akan berdampak pada volatilitas return saham yang ditanggung investor. Namun hasil ini tidak sesuai dengan penelitian yang dilakukan Hodder (2005) serta Khan dan Bradbury (2014) yang menyatakan bahwa volatilitas laba komprehensif berpengaruh positif terhadap volatilitas return saham serta penelitian yang dilakukan oleh Lucchese (2020) pada perusahaan perbankan yang terdaftar dalam bursa efek di 15 negara eropa pada tahun 2011-2015 yang menunjukkan hasil volatilitas laba komprehensif memiliki pengaruh positif terhadap volatilitas return saham.

\section{Pengaruh Volatilitas Komponen-Komponen OCI terhadap Volatilitas Return Saham}

Hasil pengujian hipotesis ketiga terkait volatilitas komponen-komponen OCI menunjukkan hasil hasil yang berbeda. Hasil pengujian hipotesis 3a-3d yaitu pada variabel volatilitas surplus revaluasi, keuntungan (kerugian) aktuaria atas program manfaat pasti, keuntungan (kerugian) selisih kurs atas penjabaran mata uang asing, keuntungan (kerugian), keuntungan (kerugian) instrumen keuangan yang tersedia untuk dijual menyatakan bahwa komponen-komponen tersebut tidak berpengaruh terhadap volatilitas return saham. Pengujian hipotesis 3e pada variabel volatilitas keuntungan (kerugian) bagian efektif atas lindung nilai arus kas menujukkan hasil yang berbeda. Komponen OCI ini berpengaruh positif terhadap volatilitas return saham yang artinya para investor mempertimbangkan komponen OCI sebagai risiko yang relevan dalam pengambilan keputusan investasi yang dilakukannya.

Investor melihat komponen OCI keuntungan (kerugian) bagian efektif atas lindung nilai arus kas tersebut sebagai risiko, karena nilainya benar-benar disisihkan oleh manajemen sebagai proteksi untuk menjaga ketersediaan arus kas agar kondisi perusahaan stabail. Tujuannya untuk menghadapi risiko ketidakpastian serta memastikan keuntungan atau kerugian atas instrument yang dilindung nilai. Instrumen derivatif biasanya menggunakan model yang kompleks dan membutuhkan asumsi dalam pengukurannya. Sehingga unsur subjektifitas dalam proses asumsi tersebut akan menjadi tinggi. Artinya semakin besar aktivitas perusahaan dalam dalam melakukan lindung nilai, bagi investor menjadi informasi risiko yang relevan dalam mengantisipasi volatilitas pada return saham. Hasil penelitian konsisten dengan penelitian Black (2013) yang menemukan bahwa volatilitas keuntungan (kerugian) bagian efektif atas lindung nilai arus kas berpengaruh positif terhadap volatilitas return saham. Dan hasil penelitian Lucchese (2020) menujukkan hal yang sama yaitu volatilitas keuntungan (kerugian) instrumen keuangan yang tersedia untuk dijual berpengaruh positif terhadap tingkat volatilitas return saham (risiko pasar atau risiko yang ditanggung investor atas return saham).

Keempat komponen OCI yang belum dapat dibuktikan secara statistik pengaruhnya terhadap volatilitas return saham, ada kemungkinan komponen tersebut belum menjadi pertimbangan investor dalam menganalisis risiko informasi laporan keuangan. Komponen OCI tersebut mungkin kurang andal karena pengukurannya masih menggunakan estimasi maupun asumsi yang cenderung masih berubah nilainya dimasa yang akan datang atau komponen OCI tidak memiliki kuotasi pasar aktif sehingga membutuhkan pemahaman cukup 
bagi para investor dalam mengolah informasi tersebut. Hasil pengujian hipotesis masingmasing komponen OCI menunjukkan bahwa tidak semua komponen OCI memiliki relevansi risiko, karena hal itu belum dapat dibuktikan secara statistik. Kurangnya relevansi tersebut disebabkan beberapa hal seperti, pertama nilai dari komponen-komponen OCI relatif kecil dan tidak seluruh perusahaan mengungkapkan komponen-komponen OCI, kedua terdapat kemungkinan bahwa perusahaan yang memiliki besar nilai komponen OCI sama dengan nol memang benar-benar tidak terdapat transaksi terkait OCI atau manajemen perusahaan memang tidak berusaha untuk mengungkapkan transaksi terkait informasi nilai komponen OCI dalam laporan laba rugi dan penghasilan komprehensif lainnya (Kahareningtyas, 2016).

Selain itu, dari sisi investor dalam pengambilan keputusan investasinya para investor belum tentu menggunakan informasi terkait komponen OCI. Menurut Isti (2017) hal ini karena para investor belum memiliki kemampuan yang cukup untuk mengolah informasi pada laporan laba rugi dan penghasilan komprehensif lainnya yang mulai diimplementasikan pada tahun 2012. Sehingga terdapat dugaan bukan komponen-komponen dalam laporan laba rugi dan penghasilan komprehensif lainnya yang bermasalah, tetapi para pelaku pasar yang belum secara penuh mampu membaca dan memahami laporan keuangan yang disajikan setelah konvergensi IFRS yang diimplementasikan tahun 2012. Informasi OCI yang penuh dengan penggunaan asumsi, judgement, dan estimasi oleh manajemen perusahaan memberikan tantangan tersendiri bagi para investor untuk memahaminya.

\section{SIMPULAN, KETERBATASAN DAN SARAN Simpulan}

Berdasarkan hasil penelitian dan pengujian hipotesis yang telah dilakukan oleh peneliti, maka dapat ditarik kesimpulan penelitian ini sebagai berikut :

1. Volatilitas laba bersih tidak berpengaruh positif terhadap volatilitas return saham pada perusahaan industri keuangan dan perbankan yang terdaftar di Bursa Efek Indonesia.

2. Volatilitas laba komprehensif tidak berpengaruh positif terhadap volatilitas return saham pada perusahaan industri keuangan dan perbankan yang terdaftar di Bursa Efek Indonesia.

3. Masing-masing volatilitas komponen OCI tidak secara keseluruhan memiliki relevansi risiko. Dari hasil uji hipotesis yang dilakukan terhadap kelima komponen OCI hanya komponen OCI keuntungan atau kerugian bagian efektif atas lindung nilai arus kas yang memiliki pengaruh positif terhadap volatilitas return saham.

4. Keempat komponen OCI lainnya yaitu surplus revaluasi, keuntungan atau kerugian aktuaria atas program manfaat pasti, keuntungan atau kerugian selisih kurs atas penjabaran mata uang asing, dan keuntungan atau kerugian aset keuangan tersedia untuk dijual tidak dapat dibuktikan secara statistik memiliki relevansi risiko. Hal ini bukan berarti komponen tersebut tidak berguna atau tidak memiliki relevansi risiko, akan tetapi kemungkinan dapat disebabkan karena tidak semua perusahaan memiliki komponen tersebut dan nilai masingmasing komponen OCI cenderung relatif kecil.

\section{Keterbatasan}

Keterbatasan dalam penelitian ini adalah :

1. Masih terbatasnya penelitian relevansi risiko di Indonesia menjadi terbatasnya referensi dalam penelitian yang dilakukan oleh peneliti.

2. Hanya menggunakan sampel perusahaan yang bergerak di sektor keuangan dan perbankan Indonesia.

3. Sampel penelitian tidak mengikutsertakan perusahaan yang bergerak di sektor lain. 


\section{Saran}

Berdasarkan kesimpulan dan keterbatasan peneliti menyarankan :

1. Penelitian selanjutnya perlu dilakukan penelitian relevansi risiko terhadap seluruh perusahaan yang terdaftar di Bursa Efek Indonesia.

2. Penelitian relevansi risiko perlu dilakukan di Indonesia karena masih terbatasnya referensi jika dibandingkan dengan penelitian relevansi nilai.

3. Menambah atau mengganti variabel penelitian yang lebih sesuai dengan penelitian mengenai relevansi risiko agar dapat menyempurnakan penelitian-penelitian terdahulu.

\section{DAFTAR PUSTAKA}

Aldheimer, Thomas \& Huynh, W. S. 2014. "Value Relevance of Other Comprehensive Income". Thesis Master of Accounting \& Management Finance, Acounting Faculty Stockholm School of Economics, December 2014.

Apandi, R. Nelly, Nur. 2015. "Relevansi Nilai, Subjektifitas Other Comprehensive Income dan Kualitas Audit". Jurnal Simposium Nasional Akuntansi I8, Hal 60.

Beaver, W., Kettler, P., \& Scholes, M. 1970. "The Association Between Market Determined and Accounting Determined Risk Measures". The Accounting Review, 45(4), 654-682.

Black, Dirk E. 2013. "Return Volatility and Other Comprehensive Income Component". Working Paper.

Bloomfield, R. J., Nelson, M. W., \& Smith, S. D. 2006. "Feedback Loops, Fair Value Accounting And Correlated Investments". Rev Acc Stud. 11. 377-416.

Chambers, et al. 2007. "An Evaluation of SFAS No. 130 Comprehensive Income Disclosures”. Review of Accounting Studies. December 2007. Volume 12 Hal 557593.

Couto, \& Rosa, R. L. 2002. "Framework For The Assessment Of Bank Earnings, Financial Stability Institute". The Accounting Review. 69. 617-637.

Fama, E. 1970. "Efficient Capital Market: A Review of Theory and Empirical Work". Journal of Finance". 25.382-417.

Faiyah Isti, 2017. "Relevansi Nilai Laba Komprehensif, Other Comprehensive Income (OCI), Komponen-Komponen OCI dan Potensi Kebangkrutan untuk Pmebuatan Keputusan Investasi Saham dengan Kualitas Auditor sebagai Variabel Pemoderasi”. Skripsi. Fakultas Ekonomi dan Bisnis Unversitas Muhammdiyah Yogyakarta. Yogyakarta.

Goncharov, I., \& Hodgson, A. 2011. "Measuring And Reporting Income In Europe". Journal of International Accounting Research. 10(1). 27-59.

Hartono, Jogiyanto. 2010 . Teori Portofolio dan Analisis Investasi. Yogyakarta. BPFE UGM

Hodder Leslie D., Hopkins, Patrick E., Wahlen James M. 2005. "Risk Relevance of Fair Value Income Measures for Commercial Banks". Kelley School of Business Indiana University.

Ikatan Akuntan Indonesia (IAI). 2009. Pengaruh Perubahan Kurs Valuta Asing. Pernyataan Standar Akuntansi Keuangan (PSAK) 10.

Ikatan Akuntan Indonesia (IAI). 2011. Aset Tetap. Pernyataan Standar Akuntansi Keuangan (PSAK) 16.

Ikatan Akuntan Indonesia (IAI). 2013. Penyajian Laporan Keuangan. Pernyataan Standar Akuntansi Keuangan (PSAK) 1.

Ikatan Akuntan Indonesia (IAI). 2013. Imbalan Kerja. Pernyataan Standar Akuntansi Keuangan (PSAK) 24

Ikatan Akuntan Indonesia (IAI). 2014. Instrumen Keuangan : Pengakuan dan Pengukuran. Pernyataan Standar Akuntansi Keuangan (PSAK) 55. 
Kahareningtyas, Fitriana. 2016. "Relevansi Nilai Other Comprehensive Income dan Komponen - Komponen Other Comprehensive Income Untuk Tujuan PembuatanKeputusan Investasi".

Khan, S., \& Bradbury, M. E. 2012 . "Risk Relevance of Comprehensive Income". School of".Accountancy. 1-23.

Khan, S., \& Bradbury, M. E. 2014. "Volatility and Risk Relevance of Comprehensive Income". Journal of Contemporary Accounting \& Economics. 76-85.

Khan, S., \& Bradbury, M. E. 2015. "The Volatility of Comprehensive Income and its Association with market risk". School of Accountancy. 1-22.

Kouki, Mondher et al. 2016. "The Value and Risk Relevance of Fair Value : The Case of French Firms”. International Journal of Accounting and Financial Planning Reporting .6(2). 15-26.

Lee dan Park. 2013. "Subjectivity In Fair Value Estimates, Audit Quality and In Informativeness Of Other Comprehensive Income". Advance In Accounting, Incorporating Advances In International Accounting. 29 (2013) 218-231.

Lucchese, M., Carlo F, D., \& Incollingo, A. 2020."Risk Relevance and Volatility of Other Comprehensive Income in The Banking Sector : Evidence From European Countries". Corporate Ownership \& Control, 17(3), 187-197.

Maines, L. A., \& Mcdaniel, L. S. 2000. "Effects Of Comprehensive Nonprofessional Characteristics On Investors' Judgement : The Role Of Financial Statement Presentation Format". The Accounting Review, 75(2), 179-207.

Murhardi, Warner R. 2009. Analisis Saham Pendekatan Fundamental. PT Indeks: Jakarta.

O'Hanlon, J. F., \& Pope, P. F. 1999. "The Value Relevance Of UK Dirty Surplus Accounting Flows". The British Accounting Review, 31(4), 459-482.

Rusdiyanto dan Narsa, I. M. 2019. "The Effect of Earning Volatility Net Income and Comprehensive Income on Stock Price on Banking Companies on the Indonesia Stock Exchange". International Review of Management and Marketing. 9(6), 18-24.

Restuti, Maria Immaculata. 2006. "Pengaruh Pertumbuhan Perusahaan Terhadap Peringkat Obligasi Dan Yield Obligasi”. Jurnal Akuntansi dan Keuangan, Volume 1 No 3, 2007.

Shapiro, A. 1996. Multinational Financial Management. 5th Edition, Prentice-Hall International.

Smith, P. A., dan Tse, S. 1998. "Reporting Comprehensive Income: Does It Really Affect Stock Prices?". Journal of Corporate Accounting and Finance, 9(4), 75-86.

Shah, Attaullah dan Safiullah Khan. 2007. "Determinants of Capital Structure: Evidence from Pakistani Panel Data". International Review of Business Research Papers. Vol. 3, No. 4. $\quad$ Pp 265-282.

Suwardjono. (2013). Teori Akuntansi: Perekayasaan Pelaporan Keuangan (Edisi Ketiga). Yogyakarta: BPFE. Januari 2013.

Widiastuti, Harjanti. 2015. "Relevansi Nilai Kredit Relatif Informasi Laba Bersih dan Laba Komprehensif: Studi Dampak PSAK 1 (Revisi 2009)". Proceeding Konferensi Regional Akuntansi II, Universitas Muhammadiyah Yogyakarta, Indonesia, hal. $1-24$. 